\title{
Effects of TIG welding process on microstructure, electrical resistance and mechanical properties of Nichrome 8020
}

\author{
S. Afkhami*, A. Halvaee \\ ${ }^{1}$ School of Metallurgy and Materials Engineering, University College of Engineering, University of Tehran, \\ P.O. Box 11155-4563, Tehran, Iran
}

Received 26 September 2014, received in revised form 6 February 2015, accepted 12 October 2015

\begin{abstract}
This study investigates effects of TIG welding and welding heat input on microstructure, hardness, tensile strength, fracture mechanism, and electrical resistance of Nichrome 8020 to evaluate its efficiency after welding, especially as a heating element. The post-weld microstructure of the alloy remained austenitic. The microstructure of fusion zone consisted of columnar dendrites, equiaxed dendrites, and intermetallic carbonitrides. These precipitates nucleated and grew among subgrain boundaries. Because of grain growth, hardness and tensile strength decreased after welding, and by increasing welding heat input, these mechanical properties decreased more severely. Fractography analysis showed that fracture surfaces of all the welded samples included both brittle and ductile features. Despite grain growth, which occurred as a result of the welding process, the electrical resistance of Nichrome 8020 increased slightly after welding. No signs of welding cracks and topologically close-packed phases were observed in the heat affected zone and fusion zone of any sample.
\end{abstract}

K e y w or d s: nichrome, welding, microstructure, mechanical properties, fractography, electrical resistance

\section{Introduction}

Nichrome 8020, as a corrosion resistant alloy with high electrical resistivity, has many applications in today's industry. Benefits of nichrome as a resistance heating element is described by Davis et al. [1]. Lai explained utilization of nichrome coating for protection of critical components of gas-cooled reactors [2]. Nowadays, nichrome is widely used as heating element in industrial furnaces. For some applications, such as fabrication and maintenance of industrial furnaces, it is necessary to join nichrome to itself or other alloys. One of the joining methods, as an industrial technique, is welding. Amongst various welding techniques, Xia et al. introduced tungsten inert gas (TIG) welding as the most suitable method to study weldability of nichrome due to its flexibility in controlling welding parameters [3].

Nichrome 8020 is a solid solution, nickel-base alloy, with an austenitic microstructure [4]. Welding such an alloy may confront some difficulties, and welded microstructure may have some welding defects. These include the formation of carbides and intermetallic compounds, solidification cracking, and heat affected zone (HAZ) cracking $[5,6]$.

Many studies are carried out in the field of weldability of nickel-base alloys and superalloys. Ogborn et al. investigated effects of segregation on microstructural evolution of Hastelloy C, Inconel 625, and Inconel 718 [7]. Ojo et al. examined the fusion zone (FZ) microstructure of Inconel 738 and analyzed the microconstituents and eutectic phases induced by microsegregation [8]. Xia et al. studied weldability of nichromelaminated powder alloy to $19 \% \mathrm{Cr}-9 \% \mathrm{Ni}$ austenitic steel using TIG welding process [3]. However, the literature lacks a study of effects of TIG welding on wrought nichrome. This study investigates the effects of TIG welding process on microstructure and mechanical properties of Nichrome 8020 to evaluate its efficiency, especially as a heating element, after welding.

*Corresponding author: tel.: +98 21 61114104; fax: +98 21 88006076; e-mail address: sh.afkhami@ut.ac.ir 
Table 1. Constant parameters of welding process

\begin{tabular}{lc}
\hline Welding voltage $(\mathrm{V})$ & 17 \\
Type of welding current & DCEN \\
Electrode diameter $(\mathrm{mm})$ & 1.6 \\
Type of electrode & $\mathrm{W}-\mathrm{Th} 2$ \\
Inert gas flow $\left(\mathrm{l} \mathrm{min}{ }^{-1}\right)$ & 10 \\
Type of inert gas & Argon \\
Welding speed $\left(\mathrm{mm} \mathrm{min}^{-1}\right)$ & 30 \\
\hline
\end{tabular}

\section{Experimental}

Nichrome 8020 strips of dimensions $100 \mathrm{~mm} \times$ $20 \mathrm{~mm} \times 2 \mathrm{~mm}$, with a chemical composition by ASTM B.0344, were sanded with emery and cleaned with acetone by ultrasonic cleaning technique before welding. The welding current was changed to vary welding heat input, and three different welding currents used to join the samples were 50,65 , and $80 \mathrm{~A}$. Table 1 shows constant parameters of the welding process.

Chemical compositions were examined by quantitative quantometer and scanning electron microscopy (SEM), coupled with energy dispersive X-ray spectroscopy (EDS). Phase characterization was performed by X-ray diffraction (XRD). SEM and optical microscopy were used for fractography and microstructural characterization. Microstructural observations were carried out after polishing every sample and etching it for $90 \mathrm{~s}$ with Kaling's No. 2 reagent. Evaluation of mechanical properties was performed via tensile (in accordance with ASTM E0008) and Vickers hardness (in accordance with ASTM E0092) tests. Electrical resistance was measured by four-point probe technique.

\section{Results and discussion}

\subsection{Base metal microstructure}

Nichrome 8020, with a face-centered cubic (fcc) microstructure, is an austenitic alloy [9]. Table 2 presents chemical composition of the base metal, and Fig. 1 shows microstructural features of the base metal. These features include many polygonal-shaped precipitates located among grain boundaries and inside
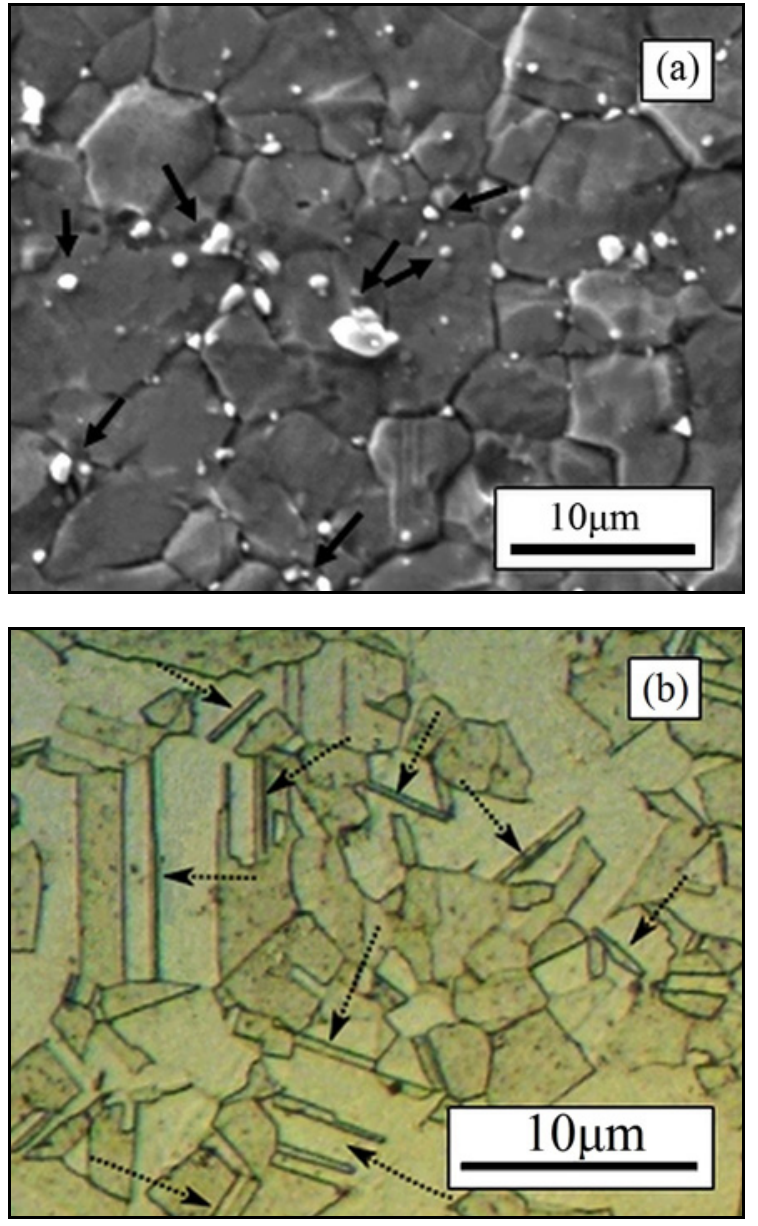

Fig. 1. (a) SEM image of Nichrome 8020 microstructure (etched for $90 \mathrm{~s}$ ), (b) optical microscope image of Nichrome 8020 (etched for $60 \mathrm{~s}$ ).

grains (indicated with black arrows in Fig. 1a). Average diameters of grains and precipitates were 10 and $2 \mu \mathrm{m}$, respectively. Figure 2 indicates that these precipitates were titanium rich carbides. According to EDS result, these precipitates dissolved chromium in themselves and formed ( $\mathrm{TiCr}) \mathrm{C}$ particles.

The high density of straight-sided substructures was another feature within austenite grains (indicated with dashed arrows in Fig. 1b). According to Fullman, these are annealing twins. A lot of annealing twins indicates that Nichrome 8020 has a low stacking fault energy $[10,11]$.

Table 2. Chemical analysis of Nichrome 8020 from quantitative quantometer

\begin{tabular}{lccccccc}
\hline Element & $\mathrm{Fe}$ & $\mathrm{Si}$ & $\mathrm{C}$ & $\mathrm{Mn}$ & $\mathrm{Cr}$ & $\mathrm{Ti}$ & $\mathrm{Ni}$ \\
\hline$($ wt.\% $)$ & $<1$ & 0.815 & 0.031 & 0.366 & 21.22 & 0.217 & balanced \\
\hline
\end{tabular}




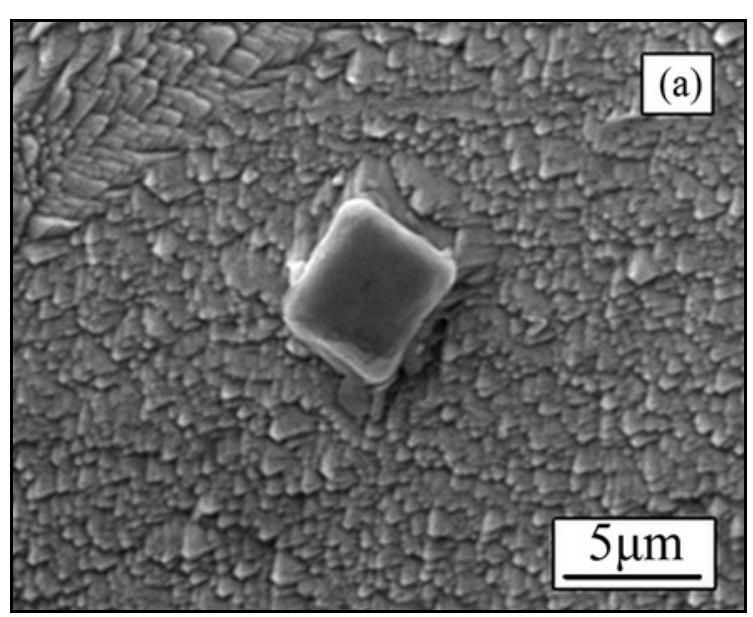

(b)

\begin{tabular}{|llll|}
\hline Element & Series & $\begin{array}{c}\text { unn. C } \\
\text { (wt.\%) }\end{array}$ & $\begin{array}{c}\text { norm. C } \\
\text { (wt.\%) }\end{array}$ \\
\hline Carbon & K Series & 4.10 & 3.97 \\
Titanium & K Series & 89.38 & 86.52 \\
Chromium & K Series & 8.19 & 7.93 \\
Nickel & K Series & 1.63 & 1.58 \\
\hline
\end{tabular}

Fig. 2. (a) SEM image of a precipitate in the base metal microstructure, (b) EDS result of the same precipitate.

\subsection{Heat affected zone microstructure}

Figure 3 shows that, because of welding heat input, grain growth occurred in the HAZ. Table 3 indicates that average grain diameter and twin length have a direct relationship with welding heat input. No sign of welding cracks and other defects was observed in the HAZ.

\subsection{Fusion zone microstructure}

Figure 4 shows that from the HAZ to the FZ, grains nucleated and grew epitaxially. Within the FZ, competitive growth let some grains grew more easily and prevented others from growing into the FZ. Grains that are adjacent to the FZ-HAZ borderline (fusion line) consisted of cellular and columnar dendrites due to a decrease in the ratio of a temperature gradient to growth rate. This ratio reaches its minimum within FZ (weld centerline). Thus, by reaching its minimum, grains nucleated heterogeneously. As a result of higher heat input, grains grew to greater sizes in this area.

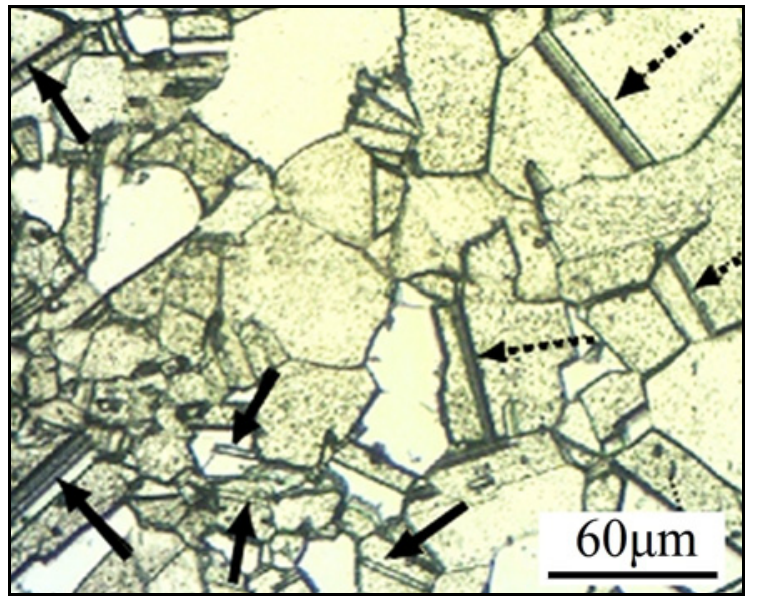

Fig. 3. Grains and twins of the base metal (black arrows) and HAZ (dashed black arrows) of the sample welded by $80 \mathrm{~A}$.

Table 3. Average grain diameters and twin lengths in the HAZ

\begin{tabular}{ccc}
\hline $\begin{array}{c}\text { Welding } \\
\text { current }(\mathrm{A})\end{array}$ & $\begin{array}{c}\text { Average grain } \\
\text { diameter }(\mu \mathrm{m})\end{array}$ & $\begin{array}{c}\text { Average twin } \\
\text { length }(\mu \mathrm{m})\end{array}$ \\
\hline 50 & 87 & 27 \\
65 & 108 & 34 \\
80 & 142 & 42 \\
\hline
\end{tabular}

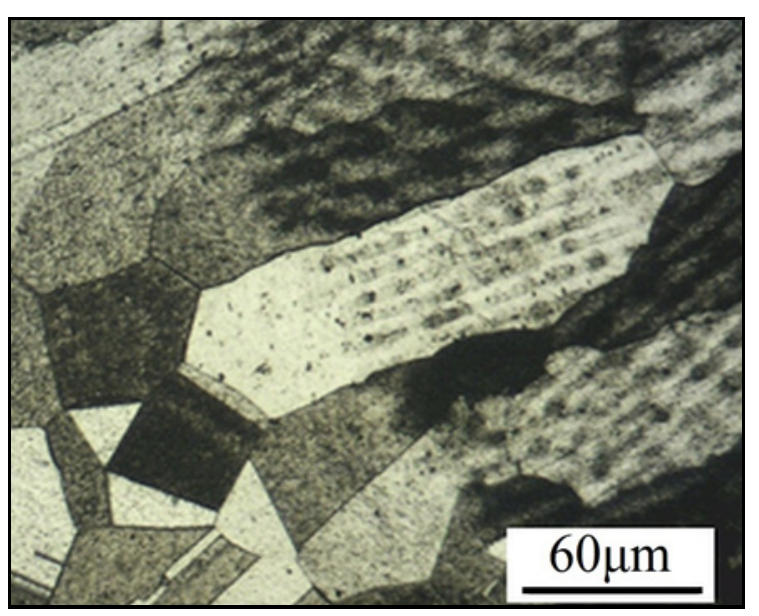

Fig. 4. The microstructure of fusion line and epitaxial growth from the welding boundary into the weld pool of a sample welded by $50 \mathrm{~A}$ welding current.

Figure 5 shows these grains, which contain a fine texture of equiaxed dendrites.

Figure 5b shows that equiaxed dendrites near the weld bead surface were finer than dendrites located in the depth of fusion zone. During welding, weld bead was in direct contact with argon and air, so it cooled 

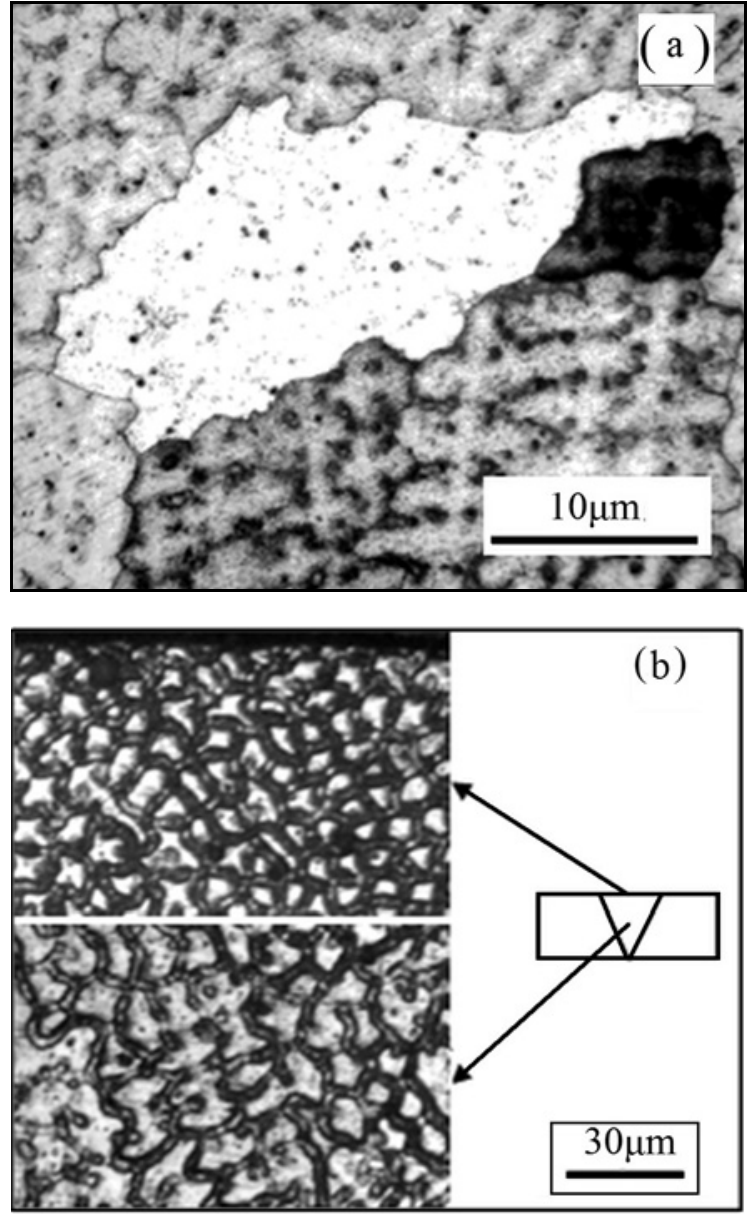

Fig. 5. (a) A solidified grain in the weld center line (welded by $50 \mathrm{~A}$ ), (b) equiaxed dendrites near weld bead surface and half depth of fusion zone of the same sample.

down faster than its underlying regions. Weld metal near the surface solidified faster, and dendrites in this region did not have sufficient time to grow, unlike the dendrites of underlying zone did.

As shown in Fig. 6, the FZ contained two types of precipitates. Firstly, silicon and chromium rich carbonitrides. Secondly, titanium and chromium rich carbonitrides. Some of these precipitates were continuous layers, located along subgrain boundaries, and others were sporadic particles with irregular shapes.

XRD results of Nichrome 8020, before and after welding, are presented in Fig. 7. This figure indicates that microstructure of nichrome remained austenitic after welding. Also, the microstructure of the FZ had no twins due to melting and solidification of the alloy.

\subsection{Hardness}

Hardness is inversely related to grain size [12]. As a result, hardness decreased after welding, as shown in Fig. 8. Increasing welding heat input resulted in larger
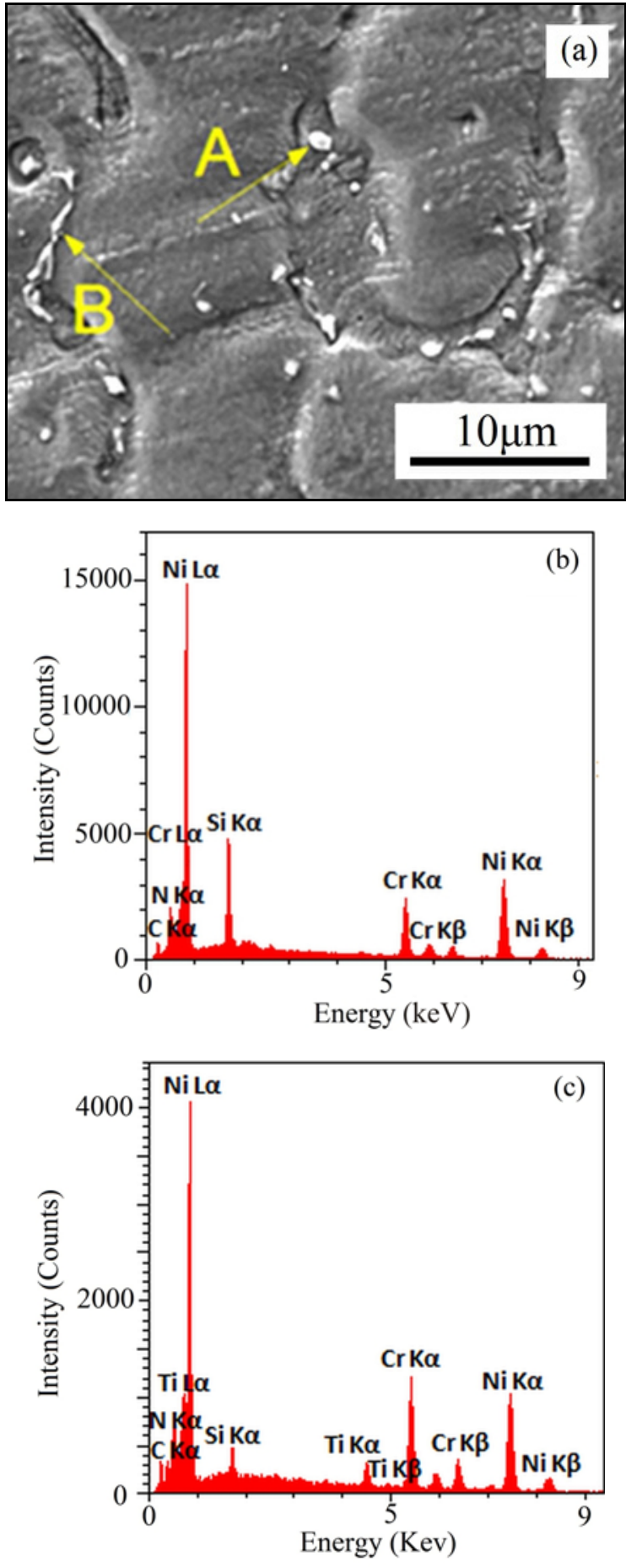

Fig. 6. (a) SEM image of precipitates of FZ (welded by $80 \mathrm{~A}$ ), (b) EDS result of precipitate A, (c) EDS result of precipitate $\mathrm{B}$.

grains. Consequently, by increasing welding heat input hardness decreased more drastically.

\subsection{Tensile strength}

Table 4 indicates that tensile strength decreased 


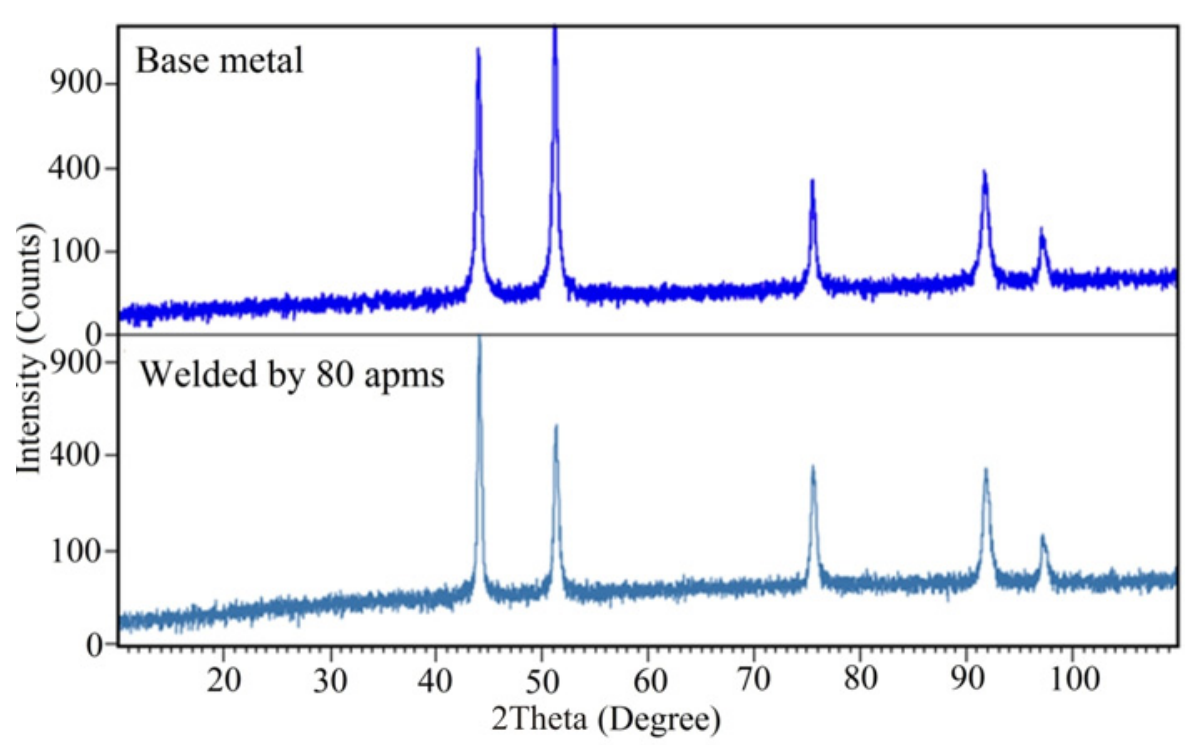

Fig. 7. XRD results of Nichrome 8020 , before and after welding by $80 \mathrm{~A}$ welding current.

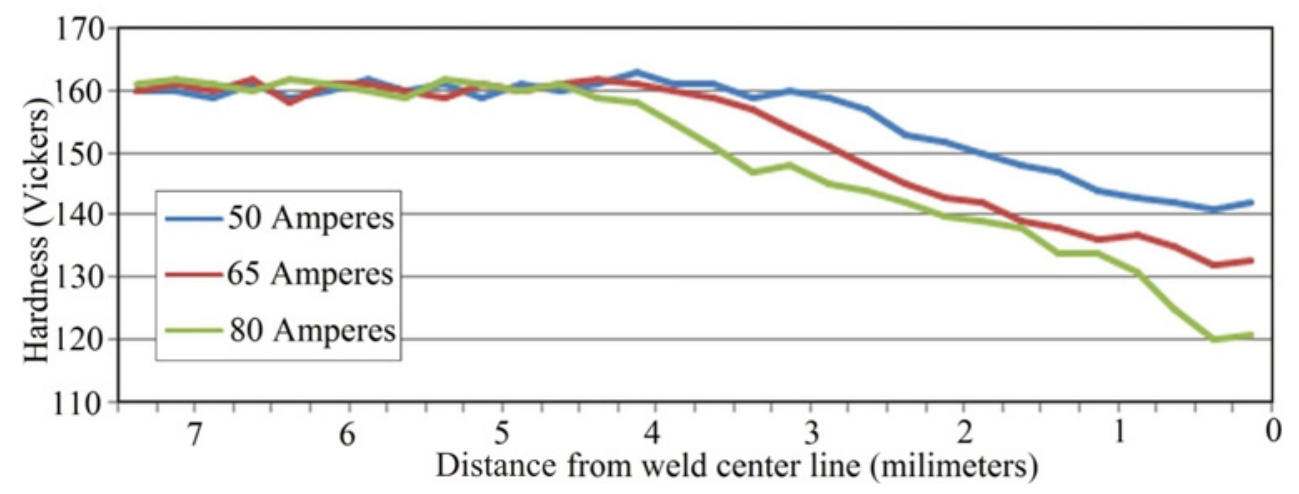

Fig. 8. Hardness profiles across samples welded by different heat inputs.

Ta ble 4. Tensile strength of the samples

\begin{tabular}{cc}
\hline Welding current $(\mathrm{A})$ & Tensile strength $(\mathrm{MPa})$ \\
\hline $0=$ Not welded & 764 \\
50 & 500 \\
65 & 487 \\
80 & 459 \\
\hline
\end{tabular}

after welding. According to Hall-Petch relationship, grain diameter and strength have been inversely related. Thus, a sample with the maximum average grain diameter (sample welded by the highest welding heat input or welding current) had the lowest tensile strength.

\subsection{Fractography and fracture mechanism}

Figure 9 shows that the not-welded sample failed

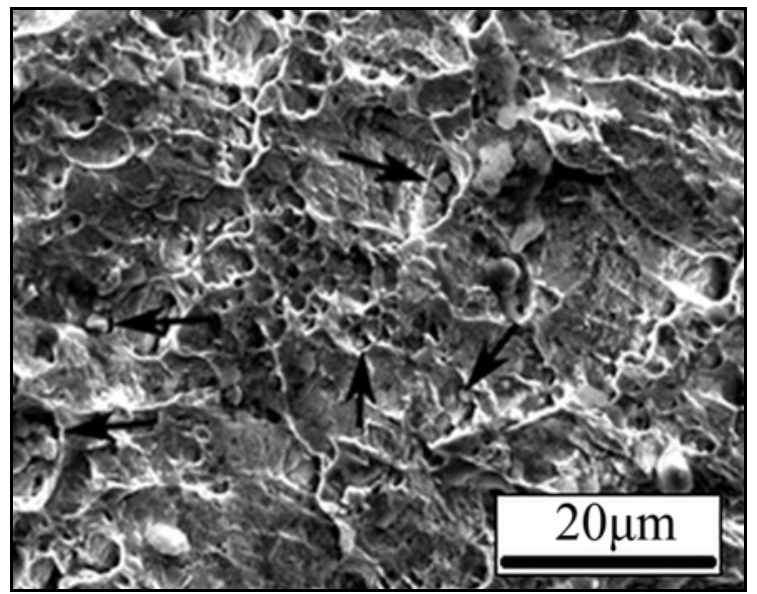

Fig. 9. The fracture surface of the not-welded sample, obtained by SEM.

by microvoid coalescence. The depth of the microvoids, known as dimples, is in direct relation to 

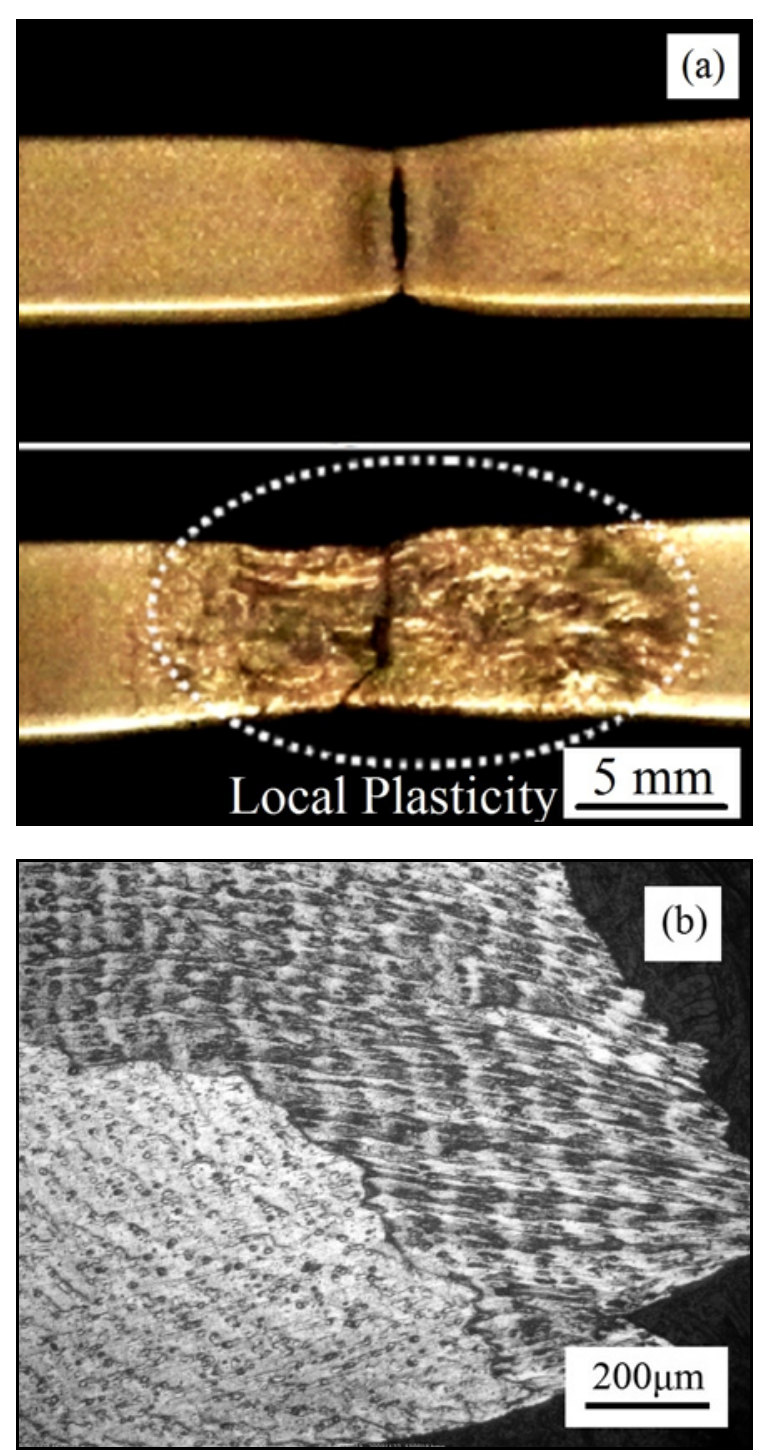

Fig. 10. Fractured specimen of (a) the not-welded sample (up) and sample welded by $80 \mathrm{~A}$ welding current (down), (b) microscopic picture of fractured area of the welded sample.

alloy ductility [13]. Uniform distribution of these dimples indicated that not-welded sample had undergone a transgranular and ductile fracture. In this kind of failure, microvoids nucleate and grow on active sites, such as precipitates. Some of these precipitates are indicated by black arrows.

Figure 10 indicates that all welded samples ruptured from FZ. Figure 11 shows a micro-crack along subgrain boundaries of a welded sample. The existence of microcracks along subgrain boundaries showed that continuous layers of brittle precipitates (as shown in Fig. 6a) may have a major effect on crack propagation during fracture of welded samples.

Figure 12 shows fracture surfaces of welded samples, which are comprised of both dimples (duc-

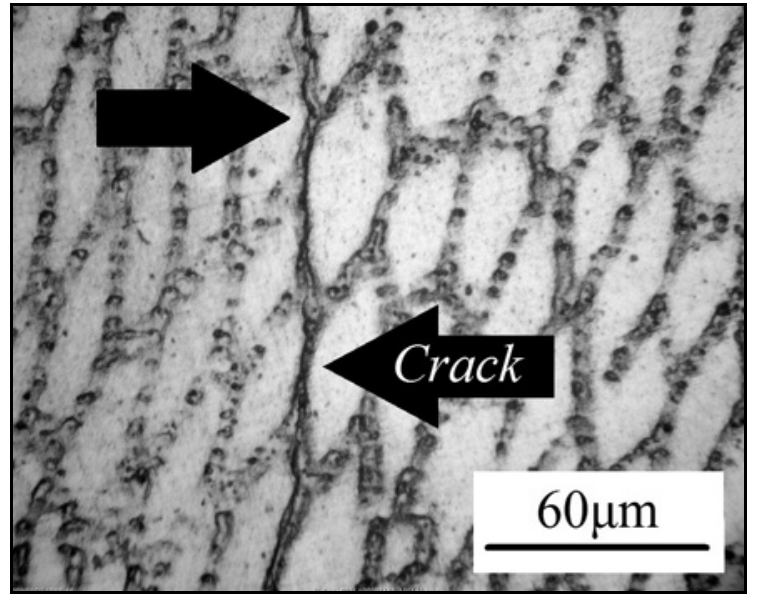

Fig. 11. A crack propagated along a subgrain boundary in the FZ of the sample welded by $50 \mathrm{~A}$.

Ta ble 5. Electrical resistance of the samples

\begin{tabular}{cc}
\hline Welding current $(\mathrm{A})$ & Electrical resistance $(\Omega)$ \\
\hline $0=$ Not welded & 4.05 \\
50 & 4.28 \\
65 & 4.26 \\
80 & 4.20 \\
\hline
\end{tabular}

tile fracture) and cleavage (brittle fracture) marks. Austenitic alloys do not normally undergo a brittle fracture with cleavage marks. These marks indicated that local brittleness occurred in welded samples. This brittleness may take place due to piling up of brittle precipitates along subgrain boundaries during weld metal solidification.

\subsection{Electrical resistance}

Table 5 gives that electrical resistance increased after welding. Grain growth decreases electrical resistance, but subgrain microstructures, such as cells, dendrites, and subgrain boundaries, act as barriers against electrical current and increase electrical resistance [14]. As a result, despite grain growth in welded samples, because of FZ dendritic microstructure and intermetallic precipitates, electrical resistance increased after welding.

\section{Conclusions}

1. Silicon-chromium and titanium-chromium carbonitrides nucleated between dendrites and subgrain boundaries in the fusion zone.

2. From fusion line to fusion zone center line, so- 

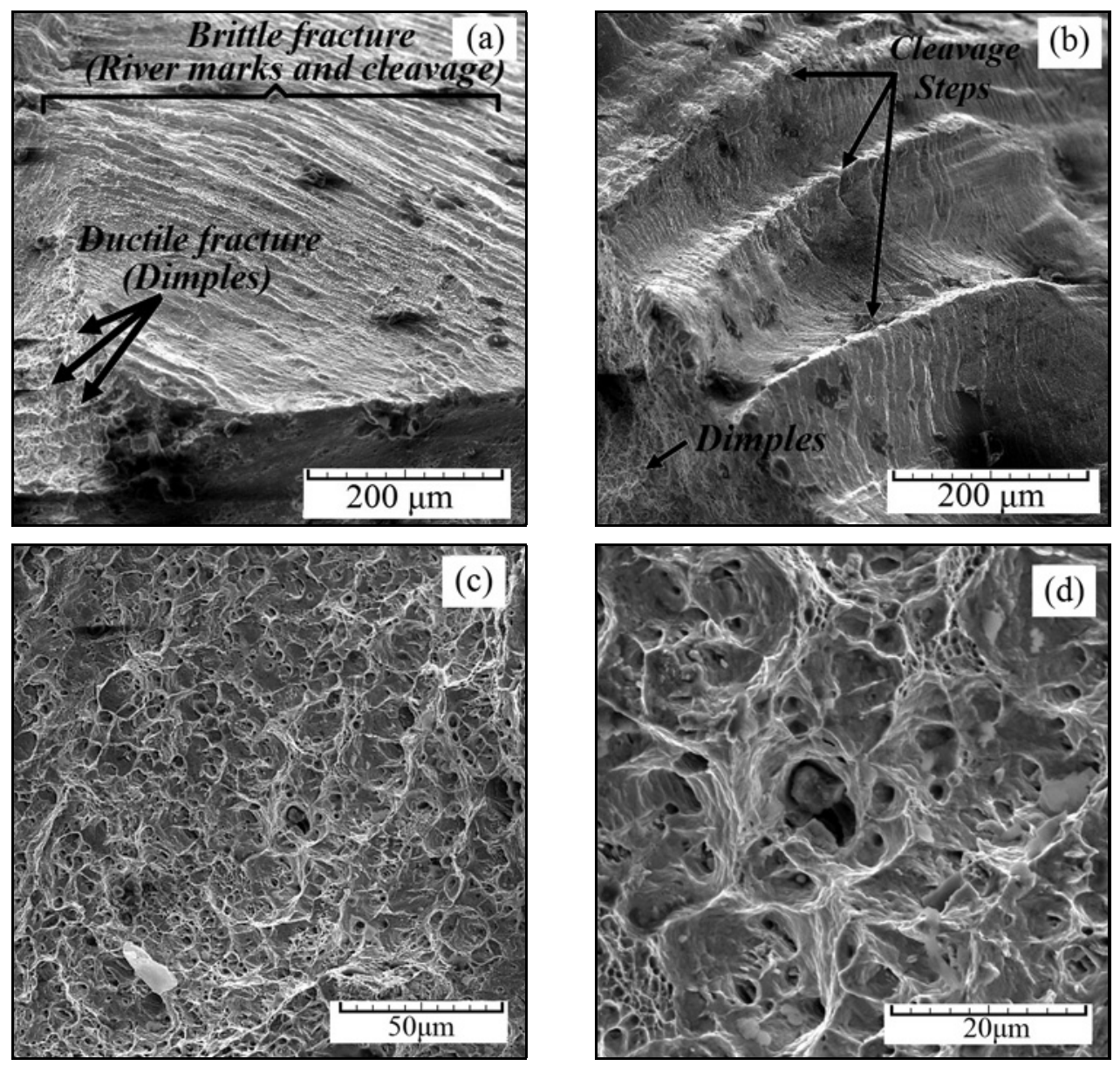

Fig. 12. (a) Fracture surface of a sample welded by $80 \mathrm{~A}$ welding current, (b) fracture surface of a sample welded by 50 A welding current, (c) dimples and precipitates in the ductile portion of the fracture surface of a welded sample, (d) precipitates within dimples.

lidification mode changed from columnar to equiaxed dendrites due to a decrease of "temperature gradient to growth rate" ratio.

3. Hardness and tensile strength decreased after welding as a result of grain growth.

4. Fracture mechanism of welded samples consisted of both brittle and ductile fractures.

5. Electrical resistance increased after welding due to the dendritic microstructure of fusion zone and intermetallic precipitates.

\section{References}

[1] Davis, J R.: ASM Specialty Handbook: Heat Resistance Materials. 1st Edition. Materials Park, ASM International 1997.

[2] Lai, G. Y.: Journal of Thin Solid Films, 52, 1978, p. 343. doi:10.1016/0040-6090(78)90227-4

[3] Xia, C. Z., Wang, J., Puchkov, U. A., Juang, Y. N.: Kovove Mater, 48, 2010, p. 257.

[4] Dupont, J. N., Lippold, J. C., Kiser, S. D.: Welding Metallurgy and Weldability of Nickel-Base Alloys. 1st Edition. Hoboken, John Wiley and Sons, Inc. 2009.
[5] Ramirez, A. J., Lippold, J. C.: Journal of Materials Science Engineering A, 380, 2004, p. 259. doi:10.1016/j.msea.2004.03.074

[6] Ramirez, A. J., Lippold, J. C.: Journal of Materials Science Engineering A, 380, 2004, p. 245. doi:10.1016/j.msea.2004.03.075

[7] Ogborn, J. S., Olson, D. L., Cieslak, M. J.: Journal of Materials Science Engineering A, 203, 1995, p. 134. doi:10.1016/0921-5093(95)09832-1

[8] Ojo, O. A., Richards, N. L., Chaturvedi, M. C.: Journal of Scripta Materialia, 51, 2004, p. 683. doi:10.1016/j.scriptamat.2004.06.013

[9] Watson, R. A., Jonsson, B., Fielding, G. A.: Electrical Resistance Alloys. ASM Metals Handbook. Volume 2. Materials Park, ASM International 1995.

[10] Fullman, R. L.: Journal of Applied Physics, 21, 1950, p. 1069. doi:10.1063/1.1699536

[11] Mahajan, S., Pande, C. S., Imam, M. A., Rath, B. B.: Acta Materialia, 45, 1997, p. 2633. doi:10.1016/S1359-6454(96)00336-9

[12] Shaw, L., Ortiz, A. L., Villegas, J. C.: Journal of Scripta Materialia, 58, 2008, p. 951. doi:10.1016/j.scriptamat.2008.01.025 
[13] Kerlins, V., Douglas, M., Phillips, A.: Modes of Fracture. ASM Metals Handbook. Volume 12. Materials Park, ASM International 1995.
[14] Hosseini, M., Yasaei, B.: Journal of Ceramics International, 24, 1998, p. 543. doi:10.1016/S0272-8842(97)00054-0 